\title{
FAKTOR- FAKTOR YANG BERHUBUNGAN DENGAN PERILAKU PENDERITA TB PARU DALAM MINUM OBAT DI WILAYAH KERJA PUSKESMAS GUNDIH KOTA SURABAYA TAHUN 2016
}

\author{
Desi Lutfianti, A.T Diana Nerawati, Ferry Kriswandana
}

ABSTRACT
Tuberculosis (TB) is an infection caused by Micobacterium tuberculosis bactery which is transmitted through the air. Surabaya contributes to pulmonary TB with highest cases and a treatment success rate of $78.8 \%$ in 2012. Behavioral factors in taking medicine is very influential in the treatment success. This research aims at determining the factors related to the behavior of pulmonary TB patients in taking medication at Gundih health center 2016.

This research is crossectional, 37 patient samples are taken by simple random sampling. Data collection is done by using oral questionnaire and written questionnaire. The data obtained and being analyzed by univariate and bivariate in form of Chi square test.

The study result shows that $78 \%$ of respondents behave (knowledge, attitude, action) well, $55 \%$ of respondents do not have Drug Taking Supervisor and $45 \%$ of Drug Taking Supervisor play their role $82 \%$ well, then $51 \%$ of TB educational media is considered unfavorable, and $87 \%$ of respondents have good family support. From these factors, family support is the factor that has significant influence with the respondent's behavior in taking medication $(P<0.05)$.

Factors related to the behavior of respondents in taking medication are related to each other so that patients can be cured with the results of Acid-Resistant Bacili (-). TB patients are suggested to to improve their knowledge. For Drug Taking Supervisor, it is suggested to motivate and remind the patients to take medication. The society are also suggested to immediately report if there are patients who have major symptoms of TB. Health centers is suggested to monitor the condition of patients' house. Finally, further researchers are expected to examine deeper the relationship between the presence or absence of the Drug Taking Supervisor with the behavior of patients with pulmonary tuberculosis in taking medicine.

Keywords : Behavioral factors, Drug Taking Supervisor, Medicines Availability, Educational Media, Family Support

\section{PENDAHULUAN}

Tuberkulosis merupakan infeksi yang disebabkan oleh bakteri Micobacterium tuberculosis. Penularan terjadi melalui udara dari droplet infeksi yang bersumber dari penderita Tb paru BTA positif yang membatukkan dahaknya (Hasan, 2005: 10). Di Indonesia, upaya penanggulangan penyakit Tb sudah dilakukan melalui strategi DOTS (directly observed treatment, Short course), yang telah terbukti dapat menekan penularan, juga mencegah perkembangan MDR Multi Drug Resistant Tb (Tb MDR) merupakan M. Tuberculosis yang resisten minimal terhadap rifampisin dan INH atau obat OAT lainnya. Rifampisin dan INH merupakan 2 obat yang sangat penting pada pengobatan Tb yang diterapkan pada strategi DOTS Soepandi, 2010). Akibat dari kejadian tersebut akan membutuhkan waktu 2 tahun untuk diobati dengan obat yang 100 kali lebih mahal dibandingkan pengobatan dengan obat standar. Mengantisipasi hal tersebut maka perlu dilakukan peningkatan kemitraan dengan berbagai pihak terutama seorang PMO
(Pengawas Menelan Obat) untuk meningkatkan ketaatan penderita dalam minum obat sehingga penanggulangan Tb secara teratur dapat tercapai (Suharmiati dan Maryani, 2011). Hasil penelitian yang dilakukan oleh Dedi Nofizar menunjukan bahwa faktor dokter, pasien, obat, dan program nasional yaitu DOTS sangat berpengaruh terhadap keberhasilan pengobatan Tb (Mulyono, 2014).

Provinsi Jawa Timur menempati urutan kedua di Indonesia dalam jumlah penemuan Tb BTA positif kasus baru. Data dari Dinas Kesehatan Jawa Timur multi drugs resistance)-Tb (Manalu,2010). Kasus Tb paru sepanjang tahun 2014 hingga Maret 2015 mencapai 40.985 kasus dengan Case Fatality Rate (CFR) sebesar 0,29\%. Kota Surabaya menempati urutan pertama di Jawa Timur sebagai penyumbang Tb paru dengan kasus hingga 4.078 (Dinkes Provinsi Jawa Timur, 2012:17).

Oleh karena itu, penurunan angka keberhasilan pengobatan perlu diwaspadai oleh seluruh Puskesmas yang ada di Surabaya, termasuk Puskesmas Gundih. Hal ini dapat terlihat dari peningkatan jumlah kasus dari 56 menjadi 66 kasus 
pada tahun 2015. Sehingga menempatkan Puskesmas Gundih dari urutan ke-20 menjadi urutan ke-16 pada tahun 2015 dari 63 Puskesmas di Surabaya. Disamping itu, angka keberhasilan pengobatan pada tahun 2014 di Puskesmas Gundih yang menurun dari $95,45 \%$ menjadi $61,54 \%$ dari tahun sebelumnya. Penurunan tersebut merupakan masalah yang harus segera ditangani dengan mengetahui faktor-faktor yang berhubungan dengan perilaku penderita dalam minum obat sehingga akan mempengaruhi keberhasilan pengobatan. Tujuan dari penelitian ini adalah mengetahui faktor- faktor yang berhubungan dengan perilaku penderita Tb paru dalam minum obat di Wilayah Puskesmas Gundih Tahun 2016.

\section{METODE PENELITIAN}

Jenis penelitian ini adalah crossectional. Lokasi penelitian dilakukan di wilayah kerja Puskesmas Gundih Surabaya Tahun 2016. Sampel dalam penelitian ini sebesar 37 sampel penderita yang sedang menjalani pengobatan. Pengumpulan data yang dilakukan dengan wawancara dan pengisian angket. Data selanjutnya dianalisis menggunakan ujichi-square untukmengetahui hubungan perilaku penderita TB paru dalam minum obat dengan peran PMO, ketersediaan obat, media pendidikan tentang Tb Paru, dan dukungan keluarga.

\section{HASIL PENELITIAN DAN PEMBAHASAN}

\section{Karakteristik Responden}

Tabel 1.

Distribusi Karakteristik Responden Umur, Pendidikan

\begin{tabular}{|c|c|c|c|}
\hline Variabel & Kriteria & $\mathbf{N}$ & $\%$ \\
\hline & Anak-anak (<15 th) & 2 & 5 \\
\hline & Produktif (15-64 th) & 34 & 92 \\
\hline & Lansia (>64 th) & 1 & 3 \\
\hline & Jumlah & 37 & 100 \\
\hline \multirow{9}{*}{ Jenis Kelamin } & Laki-laki & 17 & 46 \\
\hline & Perempuan & 20 & 54 \\
\hline & Jumlah & 37 & 100 \\
\hline & Tidak Sekolah & 7 & 19 \\
\hline & SD & 5 & 13 \\
\hline & SMP & 7 & 19 \\
\hline & SMA & 17 & 46 \\
\hline & Perguruan Tinggi & 1 & 3 \\
\hline & Jumlah & 37 & 100 \\
\hline \multirow{5}{*}{ Pekerjaan } & Tidak Bekerja & 19 & 51 \\
\hline & Wiraswasta & 7 & 19 \\
\hline & Swasta & 11 & 30 \\
\hline & PNS & 0 & 0 \\
\hline & Jumlah & 37 & 100 \\
\hline
\end{tabular}


Dari tabel 1 diketahui bahwa sebagian besar responden berumur produktif yaitu 15-64 tahun $(92 \%)$, berjenis kelamin perempuan (54\%), dengan tingkat pendidikan SMA (46\%) dan tidak bekerja (51\%). Penderita Tb paru yang berusia produktif dan berjenis kelamin perempuan tersebut sebagian besar adalah ibu rumah tangga yang waktunya banyak dihabiskan di dalam rumah sehingga apabila kondisi rumah tidak memenuhi persyaratan maka dapat beresiko terpapar penyakit Tb paru.

Tabel 2

Distribusi responden berdasarkan Perilaku dalam Minum Obat, Peran PMO, Media Pendidikan Tb paru, dan Dukungan Keluarga

\begin{tabular}{|c|c|c|c|c|c|c|c|c|}
\hline \multirow{2}{*}{ Kriteria } & \multicolumn{2}{|c|}{$\begin{array}{l}\text { Perilaku dalam } \\
\text { Minum Obat }\end{array}$} & \multicolumn{2}{|c|}{ Peran PIOO } & \multicolumn{2}{|c|}{$\begin{array}{c}\text { Media Pendidikan } \\
\text { Tb paru }\end{array}$} & \multicolumn{2}{|c|}{$\begin{array}{c}\text { Dukungan } \\
\text { Keluarga }\end{array}$} \\
\hline & $\mathrm{N}$ & $\%$ & $\mathrm{~N}$ & $\%$ & $\mathrm{~N}$ & $\%$ & $\mathrm{~N}$ & $\%$ \\
\hline Baik & 29 & 78 & 14 & 82 & 5 & 14 & 32 & 87 \\
\hline Cukup & 5 & 14 & 3 & 18 & 13 & 35 & 3 & 8 \\
\hline Kurang & 3 & 8 & 0 & 0 & 19 & 51 & 2 & 5 \\
\hline Jumlah & 37 & 100 & 17 & 100 & 37 & 100 & 37 & 100 \\
\hline
\end{tabular}

\section{Perilaku dalam Minum Obat}

Dari Tabel 2 diketahui responden berperilaku dalam minum obat baik (78\%). Perilaku kesehatan merupakan respon seseorang terhadap stimulus dalam bentuk aktivitas atau kegiatan yang berkaitan dengan pemeliharaan dan peningkatan kesehatan. Perilaku dalam penelitian ini adalah tindakan atau kebiasaan yang dilakukan responden dalam minum obat selama masa pengobatan. Penilaian meliputi pengetahuan, sikap dan tindakan responden dalam minum obat selama masa pengobatan.

Perilaku responden dalam minum obat sangat mempengaruhi hasil pemeriksaan dahak diakhir masa pengobatan selama 6 bulan. Pemeriksaan dahak penderita Tb paru dilakukan pada bulan ke-2, 5 dan 6 pengobatan. Hasil pemeriksaan dahak selama 2 bulan sangat penting untuk menentukan menular atau tidaknya kuman Tb ke orang yang rentan, namun meskipun pemeriksaan pada 2 bulan pertama menunjukkan hasil BTA (-) pengobatan pasien tidak boleh berhenti sampai fase pengobatan selesai dan dinyatakan sembuh (Erlinda, 2013). Sehingga perilaku penderita dalam minum obat selama masa pengobatan sangat mempengaruhi hasil pemeriksaan dahak.

\section{PMO}

Hasil gambaran peran PMO menunjukkan bahwa sebagian besar responden tidak memiliki PMO (55\%). Sedangkan bagi responden yang memiliki PMO(45\%), mempunyai peran PMO yang baik $(82 \%)$ dan cukup baik (18\%). Peran PMO dalam penelitian ini meliputi tindakan- tindakan PMO dalam mengawasi penderita selama masa pengobatan seperti mengecek obat, mengingatkan penderita untuk mengambil obat dan periksa dahak, mengantarkan penderita mengambil obat, menegur dan memotivasi penderita jika lalai atau bosan meminum obat serta menyampaikan informasi tentang penyakit Tb Paru kepada penderita.

\section{Ketersediaan Obat}

Pencapaian angka keberhasilan pengobatan $\mathrm{Tb}$ paru sangat bergantung pada sistem logistik yang menjamin ketersediaan obat secara kontinyu. Berdasarkan hasil penelitian terhadap 37 responden, diperoleh jawaban yang sama dari seluruh responden (100\%) bahwa Obat Anti Tuberkulosis (OAT) selalu tersedia dan lengkap pada saat pengambilan obat. Pengambilan obat dilakukan seminggu sekali untuk pasien yang menjalani pengobatan pada tahap intensif dan 2 minggu sekali untuk pasien pada tahap lanjutan.

\section{Media Pendidikan Tb paru}

Media pendidikan kesehatan merupakan alat-alat yang digunakan untuk mempermudah penerimaan pesan atau informasi kesehatan bagi masyarakat. Media pendidikan tersebut dapat berupa slide, film, radio, leaflet, ataupun pamleft. Sedangkan metode pendidikan yang dapat dilakukan terdiri dari metode pendidikan individu (bimbingan atau konseling), metode pendidikan kelompok (diskusi kelompok, seminar dan penyuluhan), metode 
pendidikan massa (ceramah, dialog dan diskusi melalui media elektronik baik TV ataupun radio, tulisan-tulisan di majalah ataupun spanduk, poster pinggir jalan) (Notoatmojo,2011:120). Berdasarkan hasil penelitian terhadap 37 responden, didapatkan gambaran bahwa sebagian besar responden kurang dalam menerima dan memanfaatkan media pendidikan Tb paru (51\%). Media pendidikan Tb paru yang dinilai terdiri dari banyaknya media yang diterima, sehingga dapat meningkatkan pengetahuan responden. Hasil penelitian menunjukkan sebagian besar responden menerima informasi dari penjelasan dokter atau tenaga perawat secara individu pada saat pengambilan obat secara rutin.

\section{Dukungan Keluarga}

Keluarga sebagai sumber dukungan sosial dapat menjadi faktor kunci dalam penyembuhan penderita penyakit $\mathrm{Tb}$ paru. Menurut Scheurer beberapa fungsi dukungan sosial sebuah keluarga adalah dukungan practical atau instrumen yang meliputi membayar obat, mengambil resep, transportasi, dan pendampingan. Kemudian dukungan emosional yang meliputi dorongan, kasih sayang, pemenuhan nutrisi, serta dukungan informasi (Maulidia, 2014). Dari tabel 2 diatas dapat diketahui gambaran bahwa sebagian besar responden memiliki dukungan keluarga yang baik. Dukungan keluarga dalam penelitian ini meliputi sikap anggota keluarga setelah responden dinyatakan menderita Tb paru dalam bentuk kesediaan anggota keluarga yang diwujudkan dalam tindakan seperti mengingatkan responden dalam minum obat, bantuan transportasi, pemenuhan kebutuhan makan, minum, istirahat dan terhindarnya dari rasa lelah serta adanya perhatian anggota keluarga terhadap kemajuan pengobatan yang dijalani responden.

\section{Hubungan Antara Peran PMO, Media pendidikan Tb dan Dukungan keluarga dengan Perilaku penderita Tb paru dalam minum obat}

Tabel 5: Hasil Uji Hubungan Antara Peran PMO, Media pendidikan Tb dan Dukungan keluarga dengan Perilaku penderita Tb paru dalam minum obat di Wilayah Kerja Puskesmas Gundih Kota Surabaya Tahun 2016

\begin{tabular}{clccc}
\hline \multirow{2}{*}{ No } & \multicolumn{1}{c}{ Variabel } & \multicolumn{2}{c}{ HASTI } & Kecimnılan \\
\cline { 3 - 5 } & P & P & $(\mathrm{P}<\mathrm{a})$ & Ada hubungan \\
\hline 1. & Adanya PMO & 1,0 & $\mathrm{P}>\mathrm{a}$ & Tidak Ada hubungan \\
2. & Peran PMO & 0,69 & $\mathrm{P}>\mathrm{a}$ & Tidak Ada hubungan \\
3. & Media Pendidikan Tb & 0,04 & $\mathrm{P}<\mathrm{a}$ & Ada hubungan \\
4. & Dukungan Keluarga & & & \\
\hline
\end{tabular}

Hasil analisis uji chi-square antara adanya PMO diperoleh nilai $\mathrm{P}=0,25>0,05$, artinya tidak ada hubungan antara keduanya sedangkan untuk peran PMO.

Hubungan antara Peran PMO dengan perilaku penderita $\mathrm{Tb}$ dalam minum obat diperoleh hasil $P=1,00>0,05$ yang berarti tidak ada hubungan antara peran PMO dengan perilaku perilaku responden dalam minum obat penderita dalam minum obat. Hal ini dikarenakan beberapa responden memiliki perilaku yang baik walaupun tidak memiliki PMO maupun pada saat peran PMO kurang baik. Penelitian ini bertolak belakang dengan penelitian yang dilakukan oleh Firdaus (2012) menunjukkan adanya pengaruh peran PMO terhadap keberhasilan pengobatan 
penyakit Tb paru, begitu juga dengan Sumange (2010) yang menemukan bahwa ada hubungan antara peran PMO dengan kepatuhan berobat pasien TB Paru. Perilaku dalam minum obat penderita yang baik ini dapat disebabkan oleh beberapa hal misalnya kemauan dan motivasi kuat yang dimiliki penderita untuk sembuh, serta pengetahuan dan pemahaman tentang bahaya dan resiko apabila pengobatan tidak dilakukan dengan teratur. Kemauan dan motivasi yang kuat dari penderita untuk sembuh ini dapat diperoleh dari adanya dukungan keluarga yang baik. Dukungan keluarga dapat diberikan secara emosional yaitu dengan memberikan motivasi dan mengingatkan penderita dalam minum obat. Sehingga dalam penelitian ini ada atau tidaknya PMO, bukanlah faktor yang menyebabkan baik atau kurang baiknya perilaku responden dalam minum obat, melainkan dukungan keluarga yang menggantikan peran PMO tersebut. Pendidikan kesehatan mempunyai peranan penting dalam mengubah dan menguatkan faktor perilaku yang dipengaruhi oleh beberapa faktor yaitu metode dan media dalam penyampaiannya (Notoatmojo, 2011). Dari hasil analisis uji chi-square antara media pendidikan Tb paru dengan perilaku penderita dalam minum obat menghasilkan $P$ =0,69>0,05 yang berarti tidak ada hubungan antara media pendidikan Tb paru dengan perilaku penderita dalam minum obat. Sebagian besar penderita menerima pendidikan Tb paru dari petugas kesehatan di Puskesmas. Pelayanan kesehatan memberikan pendidikan tentang penyakit

\section{KESIMPULAN}

1. Faktor yang berhubungan dengan perilaku dalam minum obat pada penelitian ini adalah dukungan keluarga $(P<0,05)$.

2. Karakterteristik responden berdasarkan umur, 92\% produktif (15-64 tahun), jenis kelamin perempuan 54\%, tingkat pendidikan SMA $46 \%$ dan tidak bekerja $51 \%$.

3. Perilaku responden dalam minum obat sebesar $78 \%$ adalah baik (pengetahuan, sikap
Tb paru mulai dari awal penderita terdiagnosis $\mathrm{Tb}$ paru. Selebihnya beberapa penderita tidak menerima pendidikan Tb dengan media yang lain. Walaupun demikian, gambaran perilaku penderita dalam minum obat menunjukkan sebagian besar penderita berperilaku baik, sehingga media pendidikan Tb paru tidak memiliki kontribusi yang berarti pada perilaku penderita dalam minum obat. Keluarga merupakan sumber dukungan sosial bagi seseorang yang menderita penyakit, khususnya penyakit Tb yang membutuhkan pengobatan yang cukup lama yaitu selama 6 bulan. Adanya dukungan keluarga diharapkan dapat memberikan motivasi, dan kemauan penderita untuk sembuh sehingga mempengaruhi perilaku dalam minum obatnya. Dari hasil analisis Uji Chi Square antara dukungan keluarga dengan perilaku penderita dalam minum obat menghasilkan $\mathrm{P}=0,04<0,05$, yang berarti ada hubungan antara dukungan keluarga dengan perilaku penderita Tb paru. Pernyataan ini didukung oleh penelitian Maulidia (2014) yang menyimpulkan bahwa adanya hubungan yang bermakna antara dukungan keluarga dengan kepatuhan minum obat. Perilaku penderita dalam minum obat dapat mempengaruhi keberhasilan penderita dalam menjalankan pengobatan selama 6 bulan. Faktorfaktor yang berhubungan dengan perilaku responden dalam minum obat merupakan faktor yang saling terkait satu dengan yang lain, sehingga penderita dapat sembuh pada bulan ke- 6 dengan hasil BTA (-).

dan tindakan).

4. Sebesar $55 \%$ responden tidak memiliki PMO, sedangkan yang memiliki PMO sebesar $45 \%$ dengan peran baik $82 \%$.

5. Ketersediaan obat anti Tb (OAT) responden selama masa pengobatan selalu tersedia dan lengkap pada saat pengambilan obat.

6. Sebesar $51 \%$ responden dalam menerima media pendidikan Tb paru adalah 
kurang.

7. Dukungan keluarga responden sebesar $87 \%$ adalah baik dalam mengingatkan untuk minum obat dan memberi bantuan selama responden menjalani pengobatan Tb paru.

8. Tidak ada hubungan antara adanya PMO dengan perilaku penderita dalam minum obat

\section{Saran}

1. Bagi penderita Tb paru

Penderita Tb paru hendaknya meningkatkan pengetahuan mereka tentang sumber, cara penularan dan cara pengobatan Tb paru, hal tersebut dapat dilakukan dengan banyak membaca informasi dari internet, pamflet yang ada di puskesmas ataupun meminta penjelasan dari petugas kesehatan di puskesmas.

2. Bagi PMO

Bagi masyarakat yang menjadi PMO agar senantiasa memberikan motivasi, mengingatkan penderita dalam minum obat secara teratur dan melaporkan ke petugas kesehatan jika terjadi efek samping.

3. Bagi Masyarakat

Bagi masyarakat umum perlu meningkatkan kepedulian terhadap penyakit Tb paru

\section{DAFTAR PUSTAKA}

Dinas Kesehatan Provinsi Jawa Timur.2013. Profil Kesehatan Jawa Timur Tahun 2012. Surabaya: Dinas Kesehatan Provinsi Jawa Timur

Erlinda, et al. 2013. Hubungan PMO dalam Program Directly Observed Treatment Shortcourse (DOTS) dengan Hasil apusan BTA Pasien Tuberculosis Paru di Puskesmas Tanggul Kabupaten Jember (Artikel ilmiah).Jember: Universitas Jember.

Firdaus, Kholifatul MZ. 2012. Pengaruh peranan Pengawas Menelan Obat (PMO) terhadap keberhasilan pengobatan TB Paru di Wilayah Kerja Puskesmas Baki Sidoharjo (Skripsi).Surakarta: Universitas Surakarata.

Hasan, Helmia. 2005. Buku Ajar Ilmu Penyakit Paru 2004. Surabaya; Graha Masyarakat Ilmiah Kedokteran Universitas Airlangga.

Maulidia, Desy Fitri. 2014. Hubungan antara Dukungan Keluarga dan Kepatuhan Minum Obat pada Penderita Tuberkulosis di Wilayah dan tidak ada hubungan antara peran $\mathrm{PMO}$ dengan perilaku penderita dalam minum obat $(P>0,05)$.

9. Tidak ada hubungan antara media pendidikan $\mathrm{Tb}$ paru dengan perilaku penderita dalam minum obat $(P>0,05)$.

dengan segera melapor ke petugas kesehatan apabila terdapat penderita yang memiliki gejala utama Tb yaitu batuk berdahak selama lebih dari 2 minggu untuk diperiksa lebih lanjut.

4. Bagi Puskesmas

Bagi Puskesmas yang dijadikan tempat penelitian agar memantau kondisi rumah penderita serta lebih memanfaatkan media cetak seperti leaflet dan poster tentang penyakit $\mathrm{Tb}$ sebagai media informasi bagi penderita.

5. Bagi penelitian selanjutnya

Diharapkan pada peneliti selanjutnya dapat meneliti lebih dalam hubungan antara ada atau tidaknya PMO dengan perilaku penderita Tb paru dalam minum obat.

Ciputat Tahun 2014(Skripsi). Jakarta:Universitas Syarif Hidayatullah

Mulyono,2014. Faktor-Faktor Determinan Kejadian Multi Drugs Resistance Tuberculosis di Indonesia. Semarang.Program Studi S1 Kesehatan Masyarakat, Universitas Dian Nuswantoro : 14

Notoatmodjo,Soekidjo.2011. Kesehatan Masyarakat Ilmu dan Seni. Jakarta: Rineka Cipta

Soepandi, Priyanti $\quad$ Z. 2010. Diagnosis dan Penatalaksanaan Tb-MDR. CDK. 180: $497-501$

Suharmiati dan Maryani,H.(2011). Analisis Hubungan Penggunaan Obat FDC/ Kombipak Pada Penderita yang di diagnosis TB Paru Berdasarkan Karakteristik. Buletin Penelitian Sistem Kesehatan. 14:2 